\title{
Valaistus osana
}

\section{elvyttävää}

\section{ympäristökokemusta}

\author{
Heli Nikunen
}

Kirjoitus perustuu Heli Nikusen vuonna 2013 hyväksyttyyn väitöskirjatyöhön Aalto-yliopiston Sähkötekniikan korkeakoululle: Perceptions of lighting, perceived restorativeness, preference and fear in outdoor spaces.

Kirjallisuudessa on jo kauan ollut kuvauksia luontoympäristön elvyttävästä vaikutuksesta ja suomalaiset ovat intuitiivisesti osanneet hakea lohtua ja mielenrauhaa metsistä ja järvien rannoilta. Viime vuosikymmeninä ympäristön elvyttävää vaikutusta on tutkittu myös tieteellisesti. Verenpaineen lasku, mielialan koheneminen ja parempi keskittymiskyky ovat eräitä elpymiseen liitettyjä positiivisia vaikutuksia (esim. Park ym. 2010). Näitä positiivisia vaikutuksia on selitetty kahden toisiaan täydentävän teorian avulla, joista toinen on korostanut psykofysiologista stressistä elpymistä (Ulrich 1991) ja toinen tarkkaavuuden elpymistä (Kaplan \& Kaplan 1989).

Kaupungeissa viheralueet ovat tärkeitä elpymisen ja stressin säätelyn paikkoja lähialueiden ihmisille. Tarve virkistäytymiselle on usein suurin iltaisin, päivän uurastuksen jälkeen (Kant ym. 2003). Tällöin ulkovalaistuksella voi olla merkittävä vaikutus elpymisprosessille.

Ulkovalaistuksen tutkimuksessa on lähtökohtana usein ollut vieraassa ympäristössä liikkuva pelokas ihminen, joka suorittaa erilaisia näkötehtäviä, kuten kasvojen tunnistusta (esim. Boyce ym. 20oo). Pelokkaan ympäristön tarkkailijan rooli voi olla merkittävä erityisesti vieraissa ympäristöissä. Ihmisille tutun arkiympäristön valaistustarpeet voivat kuitenkin huomattavasti poiketa tästä 
oletuksesta. Erityisesti kodin lähiympäristö voi olla mielihyvän, rentoutumisen ja leikin paikka. Valaistuksen tulisikin tukea myös näitä tarpeita.

Väitöskirjatyössäni ulkovalaistus nähdään tekijänä, jolla voi olla ratkaiseva vaikutus pimeän ajan ulkotilojen laatuun. Väitöskirja tutkii ulkovalaistuksen elvyttävyyspotentiaalia tarkkaavuuden elpymisen teorian tarjoamassa viitekehyksessä sekä valaistuksen vaikutusta turvallisuuden tunteeseen ja miellyttävyyteen. Näillä tekijöillä voi olla merkittävä vaikutus ulkotilojen käyttöön pimeän aikaan ja tyytyväisyyteen omaan asuinalueeseen. Väitöskirjan tavoitteena on ollut selvittää, kuinka havainnot ulkovalaistuksen laadusta liittyvät havaintoon elvyttävyyspotentiaalista.

Tarkkaavuuden elpymisen teorian juuret ovat Rachel ja Stephen Kaplanin 1970-luvulla tekemissä tutkimuksissa. Teorian mukaan keskittymistä vaativa toiminta voi johtaa uupuneisuuteen, jonka tunnusmerkkejä ovat muun muassa vaikeus keskittyä, ärtyneisyys ja jopa aggressiivisuuden kasvu. Tarkkaavuuden elpymisen on nähty olevan tehokkaampaa luontoympäristössä kuin kaupunkiympäristössä (esim. Hartig \& staats 2003). Parempaa elvyttävyyttä on selitetty evoluution avulla (Kaplan \& Kaplan 1989). Lisäksi on esitetty, että luonnonympäristöjen välittämää visuaalista informaatiota prosessoidaan tehokkaammin esimerkiksi niiden fraktaalisesta luonteesta johtuen (Joye \& van den Berg 2011). Rakennetut ympäristöt taas edellyttäisivät suunnatun tarkkaavaisuuden käyttöä, jossa energiaa kuluu siihen, että torjutaan tarpeetonta informaatiota. Kaupunki-luonto-kahtiajaon lisäksi erityisesti länsimaiselle elvyttävyystutkimukselle on ollut luonteenomaista keskittyä nimenomaan visuaaliseen kokemukseen. Sen sijaan Japanissa elvyttävyystutkimus on ollut moniaistisempaa (Tsunetsugu ym. 2010).

Elpymiskokemuksen keskeisten komponenttien on esitetty olevan arjesta irtautuminen, lumoutuminen, sopivuus omiin tarpeisiin ja näkymästä välittyvä ulottuvaisuuden ja yhtenäisyyden tunne (Kaplan \& Kaplan 1989). Tarkkaavuuden elpymisen teoria ei ole suoraan käsitellyt valaistuksen elvyttävää vaikutusta. Kaplanit ovat kuitenkin nähneet valon potentiaalisena lumoutumisen tunteen lähteenä. Lumoutumisen tunne voi heidän mukaansa syntyä esimerkiksi auringon laskua tai liekkien tanssia katseltaessa. Voidaan myös olettaa että lehvästön läpi siivilöityvä valo tai veden pinnasta heijastuva valo koetaan elvyttävinä. Niissä molemmissa on lumoavaa valon välkettä. Lisäksi ne kantavat viestiä luonnon - puiden ja veden läsnäolosta.

Paitsi että valo itsessään voi saada aikaan lumoutumisen tunteen, myös se tapa, jolla valo paljastaa ympäristömme katsottavaksemme, voi vaikuttaa elvyttävyyteen. Valo paljastaa ja ohjaa katsetta. Mitä me näemme, kun katsomme ympärillemme kaupungissa auringon laskettua? Me näemme teitä, parkkipaikkoja ja kylttejä, sillä nämä ovat niitä asioita, joita pimeän aikaan 
valaisemme. Valonkäyttötapamme manipuloi pimeän ajan visuaalisen kauVÄITös punkiympäristön erittäin teknis-urbaaniksi ympäristöksi. Tiet, parkkipaikat ja kyltit ovat myös niitä asioita, joista pidetään vähiten päiväajan ympäristöissä ja joista muodostuneet ympäristöt ovat vähiten elvyttäviä.

Ensimmäisten osatutkimusten hypoteesina oli, että valon kohdistaminen luonnonympäristöön liittyy kokemukseen paremmasta elvyttävyyspotentiaalista, vähäisemmästä pelon tunteesta ja ympäristöstä pidetään enemmän, kuin jos valoa kohdistetaan rakennetusta ympäristöstä koostuviin näkymäsisältöihin. Tutkimusmenetelmä perustui subjektiivisiin arviointeihin simuloiduista ympäristöistä. Simuloituja ympäristöjä valaistiin kahdella eri tavalla kohdistaen valoa joko viherympäristöön tai rakennettuun ympäristöön. Koettu kirkkaus ja valaistu pinta-ala kuvaparien välillä pidettiin samana. Valaistussimulaatioiden tulokset tukivat hypoteesia. Valon kohdistaminen joko viherympäristöön tai rakennettuun ympäristöön vaikutti havaittuun elvyttävyyspotentiaaliin, turvallisuuden tunteeseen ja preferenssiin. Havaittu elvyttävyyspotentiaali, turvallisuuden tunne ja preferenssi olivat suurempia, kun valo kohdistui viherympäristöön. Valon kohdistaminen teihin, rakenteisiin ja parkkipaikkoihin laski elvyttävyyspotentiaalia, preferenssiä ja turvallisuuden tunnetta.

Valaistuksen muiden osatekijöiden vaikutusta tutkittiin kenttäkokeiden avulla. Viittä valaistua ympäristöä arvioitiin sekä kyselykaavakkeen avulla että vapailla kommenteilla. Kenttäkokeiden tulokset vittasivat siihen, että kokemus ympäristön elvyttävyydestä voi liittyä kokemukseen miellyttävästä valon väristä. Miellyttävä valon väri oli yhteydessä myös turvallisuuden tunteeseen ja miellyttäväksi koettuun valaistusympäristöön. Koealueina käytetyissä lähiöympäristöissä miellyttäväksi koettiin lämmin valon värisävy.

On myös huomionarvoista, että eräillä koealueilla valaistus koettiin liian kirkkaaksi. Tämä nousi esiin myös vapaissa vastausosioissa, joissa kirkkaus yhdistyi usein negatiivisiin kuvauksiin. Valaistua ympäristöä saatettiin kuvata esimerkiksi kovaksi ja kolkoksi. Tulos haastaa oletuksen, että ihmiset kaipaavat voimakasta valonkäyttöä. Valonkäytön tulee olla sopiva suhteessa toimintoihin ja valaistun ympäristön kokonaisrakenteeseen. Hämäräksi kuvattu valaistus ei välttämättä ole riittämätön eikä kirkas sopiva.

Väitöskirjan tulosten perusteella turvallisuuden tunnetta ja viihtyisyyttä voi parhaiten edistää kohdistamalla valoa miellyttäviin näkymäsisältöihin ja käyttämällä valonlähteitä, joiden väriominaisuudet koetaan miellyttäviksi. Väitöskirjatyössä käytettiin elvyttävyystutkimuksille tyypillistä kaupunki luonto -vastakkainasettelua. Täytyy kuitenkin huomioida, että myös kaupunkiympäristössä voidaan kokea elvyttäviä tunteita. Erityisesti ympäristöt, joilla on historiallista ja sosiaalista merkitystä, ovat usein pidettyjä. Kaupunkien 
historiallista kerrosta ja tarinallisuutta tulisi laajemmin nivoa osaksi kaupunkisuunnittelua ja kaupunkikokemusta. Valon määrä oli merkittävä turvallisuuden tunteeseen ja miellyttävyyteen vaikuttava tekijä, mikäli valaistustaso oli erittäin alhainen tai epämiellyttävän suuri. Tulosten tulkinnassa tulee kuitenkin ottaa huomioon, että kyseessä on valaistustutkimukselle täysin uusi viitekehys ja lisätutkimukset ovat tarpeen.

Valaistuksen vaikutukset muun muassa näkötehokkuuteen, mielialaan ja vireystilaan ovat jo saaneet laajalti huomiota. Väitöskirjatyöni esittää, että valaistuksella voi olla myös aiemmin tuntemattomia vaikutuksia tarkkaavuuden elpymiseen. Ympäristön elvyttävyyden teoriat ovat korostaneet urbaani-luonto -kahtiajakoa. Suurin osa ympäristöistä, joissa ihmiset liikkuvat ovat kuitenkin erilaisia sekaympäristöjä, joissa huomion kohdistumisella erilaisiin elementteihin voi olla ratkaiseva merkitys ympäristökokemukselle. Kaupungeissa tulisi ottaa myös pimeän ajan ympäristön elvyttävyyspotentiaali huomioon.

KIRJALLISUUS

Boyce, Peter R. \& Eklund, Neil H. \& Hamilton B.J., \& Bruno L.D. (2000). Perceptions of safety at night in different lighting conditions. Lighting Research and Technology 32, 79-91.

Hartig, Terry \& Henk, Staats (2003). Guest editors introduction: restorative environments. Journal of environmental Psychology 23, 103-107.

Joye, Yannick \& van den Berg, Agnes (2011). Is love for green in our genes? Acritical analysis of evolutionary assumptions in restorative environments research. Urban Forestry \& Urban Greening 10:4, 261-268.

Kant, I.J. \& Bültman, U., \& Schröer, K.A.P. (2003). An epidemiological approach to study fatigue in the working population: the Maastricht Cohort Study. Occupational and Environmental Medicine 6o(suppl 1), i32-i39

Kaplan, Rachel \& Kaplan, Stephen (1989). The Experience of Nature: A Psychological Perspective. New York: Cambridge.

Park, Bum Jin \& Tsunetsugu, Yuko \& Kasetani, Tamami \& Kagawa, Takahide (2010). The physiological effects of Shinrin-yoku (taking in the forest atmosphere or forest bathing): evidence from field experiments in 24 forests across Japan. Environmental health and preventive medicine.

Tsunetsugu, Yoko \& Park, Miyazaki (2010). Trends in research related to "Shinrin-yoku" (taking in the forest atmosphere or forest bathing) in Japan. Environmental Health preventive medicine 15:1, 27-37.

Ulrich, Roger S. \& Simons, Robert F. \& Losito, Barbara D. \& Fiorito, Evelyn \& Miles, Mark A. \& Zelson, Michael (1991). Stress recovery in natural and urban environments. Journal of Environmental Psychology 11, 201-230 